\title{
Recent Memoir: Butterscotch, Black Chairs, and Breeders
}

A review of Encyclopedia of an Ordinary Life by Amy Krouse Rosenthal (Crown, 2005), Songs from the Black Chair by Charles Barber (Nebraska, 2005), and Accidental Species by Kass Fleisher (Chax, 2005).

"I was not abused, abandoned, or locked up as a child," Amy Krouse Rosenthal writes early in Encyclopedia of an Ordinary Life, signaling the reader not to expect that kind of memoir: "My parents were not alcoholics, nor were they ever divorced or dead. We did not live in poverty, or in misery, or in an exotic country.... I have not lived to tell."

If the first turn in the history of memoir was the realization that unfamous people, too, could write memoirs, the next logical group to emerge is obscure people to whom not much has happened. The Seinfeldian memoirist, if you will: this show is about nothing. Actually, Rosenthal's catalogue of the ordinary isn't novel, as she herself points out-her model is Sei Shonagon, an eleventh-century Japanese lady-in-waiting who wrote charming short prose pieces with titles like "Awkward Things," "Things That Fall from the Sky," and "Oxen Should Have Very Small Foreheads."

In alphabetical entries, each one an essayette of a sentence to a few pages, Rosenthal seeks to capture the moments between the dramatic moments of our lives. Casual as a passing thought, they sketch an idiosyncratic model of the self: one more random and jumbled, less linear and narrative-driven, than the usual autobiographical construction. Cross-references encourage skipping around, and whimsical line drawings by Jeffrey Middleton, who illustrated Webster's Dictionary, lie scattered about.

Some of Rosenthal's aphorisms are spot-on ("Travel": "In the end, no one really wants to hear about your trip.") Some recollections reveal much about the narrator's world in a few words, like her entry "Brother": "My brother, who grew up with three sisters, was I won't say how many years old when he finally realized that he did not have to wrap the towel around his chest when he came out of 
the shower" (an illustration of a man with toweled torso accompanies). The entry "Clapping" both exemplifies and mocks the kind of obsessive, neurotically self-aware personality that would create a book like Encyclopedia:

Are there actually people who are so totally comfortable with themselves, so completely unself-conscious, that when they're at a concert and the band signals the audience to clap along, they can clap without thinking to themselves, I am clapping now, here I am clapping along, are most people clapping? Okay, fine, most people are clapping, but wait, the clap-along thing feels like it's losing its momentum-should I stop clapping now? I'm feeling a bit heavy-handed in my clapping, but how/when do I stop? Three more claps and I'm out. Okay, last clap. Clap. Done.

Eventually, however, the enforced arbitrariness wears thin-"I love butterscotch but rarely think to seek it out"-and the lightness of tone becomes glib: "I'm thankful for my health, my childhood, and spell-check." It makes one start to understand why completely happy people rarely write successful memoirs-it's easy to seem smug or frivolous, or as if one is hiding something.

So, what is ordinary life-specifically the early $21 s t$ century, relatively affluent American version? Pie, Q-Tip, Shower Tiles, Tears, Uneasy Conversation.... On the whole, a lot of driving around, stopping for coffee, leaving phone messages, going to Office Depot, listening to NPR, and more coffee. After several entries like this, I found myself skipping ahead to the entry titled "Dying." And it delivers: Rosenthal lets her guard down, revealing an unjokey vulnerability. That entry and "Wreck," about an accident in which her son was injured, are the most memorable moments in the book. I wanted to hear more from this side of Rosenthal.

Is it just voyeurism? Are memoir readers out for blood? Not necessarily, but diverting personal trivia and formal cleverness are not enough. (Roland Barthes exploited the formal angle first, anyway, with his alphabetically arranged 1975 autobiography Roland Barthes by Roland Barthes.) What matters most is what Virginia Woolf called the true subject of memoir, "the person to whom things happened." In "A Sketch of the Past," Woolf expresses dismay that most memoirs leave out this crucial element and instead focus on events: 
"And the events," she reiterates, "mean very little unless we know first to whom they happened." It seems an old-fashioned concept, but the search for this person (whether successful or not, whether ultimately possible or not) provides the deepest source of drama in the memoir: not trauma and loss, or even happiness and dailiness, but a soul on a journey towards knowing itself.

Rosenthal, who refuses to be defined by her suffering, instead defines herself by an amalgamation of miscellania: her lost glove, her parking tickets, her trouble with train schedules, and the exact year-1977-she used Nair for the first time. Such a gathering fails to conjure up Woolf's elusive quarry. In other words: To whom did the Nair happen?

What could be more at odds with Rosenthal's chipper tone than the F. Scott Fitzgerald line, "What people are ashamed of usually makes a good story"? In Songs from the Black Chair: A Memoir of Mental Interiors, Charles Barber takes this quote as an epigraph and a mandate.

Like Rosenthal, he warms up by introducing himself to the reader. But rather than making assertions, he hedges: states a hypothesis, half-retracts it, lets us in on in his confusion over how to, as Woolf put it, "describe oneself truly." Several contradications emerge. Blessed with material and educational advantages, son of a professor in a small New England town, Barber (like his friend Henry, also a faculty brat) stumbled along the way, fell off the success track, struggled with mental illness. After attending Andover and Harvard, he rejected the usual lucrative professions and instead took a job working with the homeless. A dingy office at Bellevue, the largest transient shelter in New York, is where Barber begins to explore in writing how his life came to take this path, and what it all has to do with Henry, who killed himself at twenty-one.

Here is a scene in which the narrator, at the age of eighteen, goes to visit Henry, who is home from the hospital after attempting an overdose:

I realize now that this was the first of two moments at which Henry and I could have changed the essentially superficial tenor of our relationship. But we both let it pass that afternoon.

It never occurred to me to ask: 


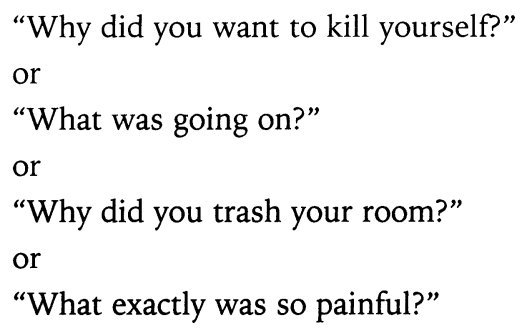

This missed connection-the two boys talk at length but, as it were, on idle about Elvis Costello-reverberates throughout the narrator's life: he goes on to become a case manager for mentally ill homeless men, asking the same direct questions of strangers, as they sit in the black chair in his office, that he could not bring himself to ask his friend. Barber seems aware of this pattern but does not belabor it. Instead he allows tales from his current work to twist around and through his memory of Henry's short journey.

The author's own struggle with obsessive-compulsive disorder is grueling to read: at one point he fills half a page with the word "black" to demonstrate the uncontrollable, irrational thoughts that played on a feedback loop in his mind. But there are moments of levity, too, as when he describes taking Prozac for the first time: "I bought a Diet Coke and swallowed the pills at once. I wondered at the marvels of late twentieth-century science, which could produce two such entirely synthetic substances. If Prozac was as good a product as Diet Coke, I thought, I was in luck."

Descriptions of Barber's own mental interior flow into observations of the world around him, leading to textured portraits of both a hothouse academic community and a homeless shelter, each full of craziness. His parents' colleagues are people like Henry's father, a brilliant literary critic who can formulate sentences like "Suicide is not in my repertoire." Barber himself writes in spare prose without literary pretensions, making his two brief imaginative forays into the minds of suicidal people starkly powerful. His ability to identify fully with those around him is a dangerous gift. He can imagine Henry's suicidal thoughts because he has had them too. He is compassionate with disturbed clients because of his own experiences with OCD: as he phrases it, "I had lived in their country." One feels the narrator could easily have slipped away and been lost as well-dead or homeless-but for good luck and pharmaceuticals. 
In part this memoir is a meditation on privilege, and on how far society is willing to go for its weakest members. While in graduate school, Barber puts Prozac on his credit card and runs up a huge debt, which is not good, but far worse is what happens to his client Michael, a professorial Czech immigrant prone to psychotic episodes who, because of budget cuts, is no longer monitored by Barber or a therapist but is referred instead to "low-demand clinics that were less treatment centers than drop-in centers for patients to socialize with their peers." Michael disappears soon after this change, most likely having jumped into the East River. Venturing outside his own social milieu, Barber comes off as far more worldly than Rosenthal, whose "ordinary" seems not to include the poor, and whose awareness of class-her own and others'-is limited to statements such as "The thing that separates the insanely wealthy from the rest of us is that the insanely wealthy enlarge all their photographs."

Budget cuts and callous public policy decisions aside, why some make it and some don't remains a mystery to Barber. Henry, who had everything, died. Barber, who feared he was Henry's double, lived. Barber lets the complexity stand, resisting easy answers. A straightforward memoir of hard times and survival, his book proves the genre isn't exhausted yet. It has room for at least one more warm, wise, sincere voice.

Rather than embrace the traditions of memoir, like Barber, Kass Fleisher sets out to break with them. In this aim she is like Rosenthal, although her latest book, Accidental Species, could not be more different. The cover illustration depicts an unhappy-looking bird splayed and pinioned like a scientific specimen. Fleisher, too, wants to avoid being pinned down, and even the book's genre evades capture. Her language is compact like poetry, but more often broken into paragraphs rather than into lines. The narrator interrupts herself to deliver parenthetical messages such as: "nota bene: this is not poetry," and "excuse me, but is this fiction?"

Fleisher resists choosing between poetry and prose, fiction and nonfiction. She plays with the traditions of poetry, essay, memoir, and experimental writing, mixing them in deliberately jarring ways. Centrally, she confronts certain unspoken assumptions: that experimental writing is not confessional; that women's writing is not experimental; that experimental writing is not by women. 
"There's never been a woman's autobiography."-again Virginia Woolf, in a letter to a friend- "Nothing to compare with Rousseau. Chastity and modesty I suppose have been the reason." Encouraging her friend to write, she added, "Now why shouldn't you be...the first woman...to tell the truths about herself? Isn't the great artist the only person to tell the truth?" Woolf's urgings found respondents during second-wave feminism, when "the personal is political" was the motto. Many more women's takes on a range of topics-family, relationships, emotions, and sexuality-were duly brought into the public sphere.

But by this point there is a tendency to talk too simplistically about women "telling their stories," as if all such stories were alike, as if they were all told in the same way-which leads to more texts that fit the mold. The resulting danger is that autobiographical writing-especially by women-is too easily dismissed as therapeutic, self-centered, nonliterary: anything but Art with a capital A. Become anything like confessional, and your seriousness comes under suspicion-you become Sylvia Plath.

Fleisher emerges with artistic cred intact; inscrutability and complexity are in abundance here. It takes nerve to use the word "subhegemonic" in the first sentence of one's book. Those who make it through that sentence- "On the day the space shuttle flew overhead, she stood once more, words arranged, and articulated a subhegemonic self, to comprehensive disaster"-are rewarded with the direct plainness of the second sentence, "I hate it when the soap slips through my fingers and crashes in the bathtub, he said." This alternation continues in different ways throughout the book: from the highly academic to the quotidian and domestic; from the simple to the indecipherable; from the abstract to the concrete. It is the language of a narrator trying to articulate the diverse areas of her life. Her layering of the different registers of language we use regularly reveals how strange a sentence said at one point in one's day can sound at a different moment, and how we constantly switch among the most various kinds of speech.

Despite the difficulty of Fleisher's style, she flirts with the ground-level connection that the confessional mode offers. Many of the chapter titles are straight from the template of a woman's life according to the New York Times style section: "Engagement," "Women in Love," "Breeder's Digest," "Honeymoon." But looks 
are deceiving. "Engagement," for instance, reads like an absurdist play between an unnamed "he" and "she": "Over my dead corpse, she redundanced.... You can come at my reading, he misspoke at the wheel." "Women in Love" seems to be in the voice of an older woman berating a younger relative, whose voice is absent, except perhaps in cryptic interruptions like "[not poetry, this]" and, later, "[knot poet tree]."

Gradually a portrait of sorts emerges: a woman trying to make sense of her family, her body, her relationships, her work. Reproduction, and the lack thereof, is a central theme: The narrator at one point describes herself as "A 2-gravida female. Redhead. Current status unknown," at another point as "predisposed to miscarriages." Accidental species are "rare birds that do not breed regularly or occur annually in North America, but whose presence has been accepted by the American Ornithologist's Union," and here at last is a label the narrator can identify with: "Although I do not breed regularly, my presence has been accepted in North America." Another motif is the economics of the adjunct instructor's life: as her perplexed family points out, "'Twenty thousand a year, no health insurance, with a Ph.D.?'" And tied in with womanhood and academia is an abiding, searing, often darkly funny feminist anger at patriarchy and its proponents-including one man, a stranger who pushes the narrator down at a pro-choice rally, and another man, not a stranger but a lover, who asks, when she retells the story, "Why do you get so emotional?"

Fleisher is ambivalent about the revelations her work contains: she writes in one of the most personal pieces, "Breeder's Digest," that "I live in terror of revealing our secrets but cannot stop myself from writing, nor from sitting and staring as the toner on the page stares back at me, dead, the marker of some unknown grave." One creeping doubt I had in the course of reading the book was whether Fleisher is at all being coy. Are the puns, the asides, the language games, the difficult constructions, the use of third-person "she" in talking about the narrator-are they in part a smoke screen to avoid the uncomfortable feelings described, or the uncomfortable position of sharing those feelings with the reader? Does her "terror of revealing our secrets" make her more opaque than she needs to be?

In the end, I think not. Fleisher's goal is not primarily to write about her life, but to explore the different ways one can think about 
and express oneself when it comes to the personal. The narrative subjectivity that coalesces by the end is not one that can be enclosed within narratives of adversity, struggle, triumph, and connection. It is a self that is permeated by the poetry of others, the clichés of everyday conversation, jokes and Freudian slips, and the detritus of academic discourse.

Another doubt I had concerned the endless self-awareness and self-referentiality of the book-do we end up in a space too small, a closed room of mirrors facing mirrors? Sometimes it seems that Fleisher writes a sentence, then writes a sentence commenting on that sentence, and then writes a sentence commenting on that sentence. She is so constantly examining her motives in writing what she is writing, examining others' reactions to what she is writing, etc., that sometimes the writing itself doesn't move forward. Though that, too, may be her point: we read a sentence and are conditioned to want to "move forward." Maybe we should slow down.

On the whole, the book succeeds for its willingness to step outside the boundaries of expectations-both about women's writing and about experimental writing. In a piece called "Sentencing Phase," Fleisher describes a woman writer who, under the tutelage of a redpen-wielding "master-father," follows his advice and "slashes sentences, minimalizes pain, inserts projectile plot structures...." But it doesn't last. Fleisher's book is her riposte to this kind of "advice": she nurtures long, complex sentences; eschews the linearity of plot; confronts pain. Accidental Species is a tribute to the daughter who resists fitting in with the dictates of tradition.

Like Barber, Fleisher chronicles a life that is both ordinary and anything but: while Barber seeks out dark corners of the mind and the world, Fleisher exposes the complicated texture of everyday life, revealing its unconscious absurdities and its half-buried sorrows. In their different ways, both demonstrate how each of us has a small share of the extraordinary; the Person to Whom Things Happened has always lived to tell. 